2. Statut Kyivskoho natsionalnoho universytetu imeni Tarasa Shevchenka (nova redaktsiia) vid 24.07.2015 r.

3. Polozhennia "Pro provedennia praktyky studentiv Kyivskoho natsionalnoho universytetu imeni Tarasa Shevchenka" vid 23.03.2007.

4. Z.V. Kretsan, N.Э. Kasatkyna "Praktycheskaia podhotovka studentov kak faktor povыshenyia kachestva unyversytetskoho obrazovanyia", Polzunovskyi vestnyk №3, 2005.

5. A.V.Brusykov "Shliakhy vdoskonalennia praktychnoi pidhotovky studentiv". Rezhym posylannia: https://www.isma.ivanovo.ru/attachments/803

6. Lyst MON 1/9-93 vid 07.02.09 roku "Pro praktychnu pidhotovku studentiv"

7. V.V Dryzhak, Ye.M. Yermak "praktychna pidhotovka zdobuvachiv vyshchoi osvity yak faktor efektyvnosti kompetentnisnoho pidkhodu u profesiinii pidhotovtsi fakhivtsiv", Visnyk ChNPU imeni Tarasa Shevchenka №125, 2015.

8. D.B. Panasevych Rekomendatsii pro provedennia praktyky studentiv vyshchykh navchalnykh zakladiv Ukrainy / D.B. Panasevych, A.K. Solodenko. K. : Ministerstvo osvity i nauky Ukrainy: Derzhavna naukova ustanova "Instytut innovatsiinykh tekhnolohii i zmistu osvity", 2013. - 28 s.

9. M.T. Levochko, N.L. Hres "Teoretychno-praktychna pidhotovka studentiv do vyrobnychoi praktyky", Visnyk ZhDU im. Ivana Franka №45, 2009 .

\footnotetext{
Надійшла до редколегії 29.11.18
} Рецензовано 05.12.18

L. Rutyan, Master of Pedagogy of Higher School

Taras Shevchenko National University of Kyiv, Kyiv Ukraine

ORCID 0000-0001-9609-2381

\title{
PRACTICALLY DIVIDED SEGMENT OF PROFESSIONAL PREPARATION OF STUDENTS IN HIGHER SCHOOL
}

The article deals with the problem of practical training of students of the first (Bachelor's) and the second (Master's) higher education levels and ways to increase the effectiveness of the system of practical training of students in higher education. The results of the empirical study of the student's experience in passing the practice as an integral part of the process of training specialists in higher educational institutions in accordance with the standards of educational activity and higher education. The principles and tasks of the University's educational activities regarding practical training of students, types of practical training of students are considered. The ways of improving the practical training of students of higher educational establishments, the level of mastering practical skills, methods of mastering skills, the method of assessment (selfassessment) of mastering skills, are determined, as well as the criteria of students' practical training, the problems of practical training of students and the factors influencing level of student satisfaction with passing the practice.

Keywords: higher education, educational activity, practical training, practice, educational practice, educational and industrial practice, pedagogical practice, assistant practice, research (undergraduate) practice, the effectiveness of passing the practice.

Л. Рутьян, магистр педагогики высшей школь

Киевский национальный университет имени Тараса Шевченко, Киев, Украина

ORCID 0000-0001-9609-2381

\section{ПРАКТИКО ОРИЕНТИРОВАННЫЙ СЕГМЕНТ ПРОФЕССИОНАЛЬНОЙ ПОДГОТОВКИ} СТУДЕНТОВ В ВЫСШЕЙ ШКОЛЕ

В статье рассматривается проблема практической подготовки студентов первого (бакалаврского) и второго (магистерского) уровней высшего образования и пути повышения эффективности системы практической подготовки студентов в высшей школе. Представлены результаты эмпирического исследования результативности прохождения практики студентами как неотъемлемой составляющей процесса подготовки специалистов в высших учебных заведениях в соответствии со стандартами образовательной деятельности и высшего образования. Рассмотрены принципы и задачи образовательной деятельности университета по практической подготовки студентов, виды практической подготовки студентов. Выяснено пути совершенствования практической подготовки студентов высиих учебных заведений, выделены уровни овладения навыками, методику овладения умением, методику оценки (самооценки) овладения умениями, а также определены критерии успешности практической подготовки студентов, обозначены проблемы практической подготовки студентов и факторы, влияющие на уровень удовлетворенности студента о прохождении практики.

Ключевые слова: высшее образование, образовательная деятельность, практическая подготовка, практика, учебная практика, учебно-производственная практика, педагогическая практика, ассистентская практика, научно-исследовательская (преддипломная) практика, результативность прохождения практики.

УДК 37.019.12:364-43

Я. Співак, канд. пед. наук, доц.

Державний вищий навчальний заклад "Донбаський державний педагогічний університет", Слов'янськ, Україна

ORCID iD 0000-0001-8829-2236

\section{ФУНДАМЕНТАЛЬНЕ ЗНАЧЕННЯ ФОРМУВАННЯ СОЦІАЛЬНО-КОМУНІКАТИВНОЇ КУЛЬТУРИ МАЙБУТНІХ СОЦІАЛЬНИХ ПРАЦІВНИКІВ}

Проаналізовано підходи вчених до розуміння сутності поняття "культура", "культура спілкування", "соціальнокомунікативна культура", "соціально-комунікативна культура соціального працівника". Акцентовано взаємозв'язок між особливостями соціальної роботи і якістю оволодіння комунікативними вміннями, які лежать в основі професійної компетенції соціального працівника. Розкрито зміст та охарактеризовано структуру соціально-комунікативної культури майбутніх соціальних працівників. Визначено фундаментальне значення соціально-комунікативної культури у професійній діяльності соціальних працівників.

Ключові слова: культура спілкування, комунікативні вміння, соціально-комунікативна культура, соціальнокомунікативна культура соціального працівника та ін.

Постановка проблеми. У сучасних умовах інтеграції України до європейського освітнього простору актуалізувалися новітні потреби суспільства у підготовці висококваліфікованого фахівця, здатного до ефективної роботи на рівні світових стандартів, готового до самореалізації, постійного розвитку і самовдосконалення. Практика переконливо свідчить, що лише висока освіченість особистості фрахівця, загальний культурний розвиток, ефективність міжособистісної взаємодії, майстерність професій- ного спілкування визначають його конкурентоспроможність на сучасному ринку праці.

Сьогодні для українського суспільства актуальності набуває соціально-комунікативна культура майбутніх фахівців, незалежно від їх професійного спрямування. Соціально-комунікативна культура $є$ фундаментальною структурною складовою професіоналізму майбутніх соціальних працівників, оскільки їх основною виробничою фрункцією $є$ налагодження емоційної взаємодії та 
спілкування з клієнтами. А відтак, важливим й одним із пріоритетних складників професійної підготовки $€$ формування та розвиток соціально-комунікативної культури майбутнього соціального працівника.

Аналіз останніх досліджень. Проблему формування соціально-комунікативної культури особистості досліджували: Н. Волкова, С. Мусатов, В. Тернопільська та ін. У наукових дослідженнях А. Капської, Л. Волинської, Д. Годлевської, Т. Спіріної та ін. розглядаються особливості формування комунікативної культури майбутніх соціальних працівників.

Мета статті - розкрити сутність та зміст соціальнокомунікативної культури соціальних працівників як фундаментальної складової їх професійної компетентності.

Останніми роками зростає увага наукової спільноти до професійної підготовки сучасного соціального працівника. Для виконання функції професійної комунікації 3 клієнтами соціальні працівники мають володіти високим рівнем соціально-комунікативної культури, яка $€$ фундаментальною складовою їх професійної компетентності. Через належну професійну готовність до соціальнокомунікативної діяльності у майбутніх соціальних працівників проявляються, формуються та розвиваються й інші професійно значущі якості.

Одним із найважливіших завдань професійної підготовки майбутніх соціальних працівників $€$ формування соціально-комунікативної культури, що визначається рівнем взаємодії з оточуючими та залежить від здібностей особистості. У культурологічному словнику зазначено, що якість та рівень культури у професійній діяльності залежать від соціально-економічного стану суспільства, стану розвитку знань, умінь особистості та їх практичного використання [2, с. 43].

Теоретико-методологічною основою соціальнокомунікативної культури особистості $€$ комунікативна теорія спілкування, що розглядається як засіб передачі різних форм культури суспільного досвіду людства.

Звернемося до аналізу категорії "культура спілкування", її особливостей, як до основного механізму формування соціально-комунікативної культури майбутніх соціальних працівників.

Вітчизняні науковці (Н. Волкова [1], С. Мусатов [7], Л. Петровська [8] та ін.) пріоритетного значення надають культурі спілкування у процесі формування професійних компентностей майбутніх фахівців гуманітарних спеціальностей. На їх думку, поняття "культура" $€$ специфічним способом організації та розвитку людської життєдіяльності, що представлений у духовних цінностях, а також продуктах матеріальної праці, системи соціальних норм, установок, ставлення людей до природи, до інших людей і до самих себе. Поняття "спілкування" інтерпретується багатьма науковцями у контексті взаємодії між людьми (С. Мусатов [7], Л. Петровська [8] та ін.). Дослідники наголошують, що розвиток особистості не можливий без побудови якісного процесу спілкування, оскільки саме в процесі міжособистісної комунікації відбувається не просто обмін певною інформацією, а й реалізація особистістю своєї суб'єктивності. Культура спілкування є сукупністю поєднаних знань, мовних та немовних умінь, навичок спілкування, які формувалися в ході природної соціалізації особистості, її освіти, виховання та розвитку. Така складна особистісна характеристика обов'язково включає комунікативні здібності, психологічні знання, уміння та навички спілкування, а також деякі природні властивості особистості (темперамент, характер, емоційні стани, тощо), що виявляються у процесі спілкування. Культура спілкування - це такий стан особистості, який визначається спрямованістю до використання засвоєних знань, комунікативних умінь, навичок і способів діяльності [9, с. 52]. Відтак, соціальний і комунікативний розвиток особистості органічно взаємопов'зані та взаємозумовлюють один одного.
Для того, щоб розкрити таке ключове поняття як "соціально-комунікативна культура", необхідно звернутися до наукових досліджень розуміння сутності комунікативного аспекту як здатності особистості соціального працівника до спілкування.

Ряд дослідників [3, 4, 10, 11] визначають соціальнокомунікативну культуру як рівень сформованості міжособистісного досвіду особистості, тобто взаємодії з оточуючими для того, щоб у межах своїх здібностей і соціального статусу успішно функціонувати у відповідному суспільстві. Вчений Ю. Ємельянов у своїх роботах дослідив залежність комунікативної культури від індивідуальних здібностей особистості та її соціальної мобільності. Він зазначає, що на комунікативну культуру впливають зміни, які відбуваються у суспільстві [4, с. 65].

Нам здається особливо важливим той факт, що при дотриманні етики спілкування акцент робиться на організації мовних засобів, що дозволяють забезпечити найбільший ефект у досягненні поставлених завдань спілкування. В.Грехнєв визначає "соціально-комунікативну культуру" як соціально значущий показник здібностей та умінь взаємодіяти з іншими людьми, сприймати, розуміти, засвоювати, передавати зміст думок, почуттів, прагнень у процесі розв'язання конкретних завдань [3, с. 55].

Звернення до аналізу теоретичних досліджень соціально-комунікативної культури майбутніх фахівців доводить необхідність цілісного уявлення про механізми, закономірності та принципи фрормування означеної якості майбутніх соціальних працівників у процесі професійної підготовки.

На основі проведеного аналізу та узагальнення концептуальних засад ми визначаємо соціальнокомунікативну культуру соціального працівника як комплекс морально-етичних та духовних цінностей особистості, їі комунікативних знань, мовленнєвих умінь і мовно-емпатичних якостей, якими вона керується у профресійній діяльності.

Специфіка професійної діяльності соціальних працівників проявляється у вирішенні проблем, які постають і стосуються конкретної людини, яка прямо чи опосередковано має відношення до всіх форм та видів суспільних відносин та діяльності людей. Це вимагає високого рівня сформованості у соціальних працівників соціально-комунікативної культури, від рівня якої залежить успішність виконання більшості професійних функцій.

Соціально-комунікативна культура соціальних працівників має фундаментальне значення у їх професійній діяльності. І в цьому контексті процес формування та розвитку професійної компетентності майбутніх соціальних працівників потребує реалізації таких завдань як: оволодіння теорією професійного спілкування, пізнання його структури, функцій, стилів, моральних принципів, формування соціально-комунікативних умінь і навичок, розвитку гуманістичного мислення, тощо [11, c. 12]. Фундаментом соціально-комунікативної культури соціального працівника $є$ склад його особистісних якостей та зміст його базової професійної освіти, що закладає основи як загальної, так і професійної культури, і містить підготовку: широку теоретичну, методологічну, гуманітарну, фрундаментальну, світоглядну, практичну за профрільними дисциплінами, творчу за фахом, у науково-дослідній роботі. На думку А. Капської, соціальнокомунікативна культура соціального працівника включає в себе і певні особистісні якості, норми ставлення до різних складових професійної діяльності. На її переконання, у професійній діяльності соціального працівника спостерігається диференціація прояву комунікативних якостей за ознакою їх переконливості, аргументованості, достовірності та емпатії [6, с. 38]. Позитивне сприйняття клієнтами рекомендацій від соціального працівника можливе за умов ефективної їх комунікативної взаємодії. Відтак, соціально-комунікативна культу- 
ра соціального працівника є першим і важливим інструментом їх професійної діяльності.

Відомо, що на формування професійної компетентності майбутнього соціального працівника впливають індивідуально-психологічні і соціально-психологічні чинники, зумовлені його здібностями, індивідуальнопсихологічними характеристиками (темпераментом, характером), потребами, інтересами, мотивацією, умовами соціального середовища, досвідом тощо. Для підвищення ефективності професійної діяльності соціальний працівник має досконало володіти соціальнокомунікативними інструментами, навичками поведінки міжособистісної взаємодії (застосовувати ту чи іншу модель поведінки у різних ситуаціях). Міжособистісна взаємодія соціального працівника визначається як ключове поняття його професійної діяльності тому, що саме через посередництво комунікативної взаємодії він одержує можливість здійснювати ефективні впливи на клієнта з метою його адаптації та соціалізації.

Враховуючи вищенаведене зазначаємо те, що соціально-комунікативна культура соціального працівника виступає як засіб вирішення професійних завдань, як спосіб організації визначеної системи взаємовідносин з клієнтом і як система соціально-психологічного забезпечення їх професійної діяльності. Зауважимо і те, що соціально-комунікативна культура соціального працівника підпорядковується загальним закономірностям спілкування та особливо тісно взаємопов'язана з педагогічним спілкуванням, однак вона має свої специфічні характеристики, структуру, що відповідають загальній логіці професійного спілкування. Профресійна діяльність соціальних працівників у будь-якій сфері (наприклад, соціальноправовий захист населення, соціальна діагностика взаємовідносин, профілактика девіантної поведінки, соціальна допомога, соціальна реабілітація, тощо) обов'язково має соціально-комунікативний характер [5, с. 255].

Відомо, що соціальна робота належить до соціономічного типу професій, тобто до виду професійної діяльності, у якому фундаментальне значення має культура спілкування. Складний багатоплановий процес сприйняття клієнта як об'єкта своєї професійної діяльності, встановлення контакту і взаємодії з ним, визначення його соціально-психологічних потреб, надання соціальної допомоги та послуг вимагає високого рівня соціально-комунікативної культури соціального працівника. Соціально-комунікативна культура соціального працівника $є$ основною умовою реалізації завдань таких професійних фрункцій як: консультативної, діагностичної, корекційної, превентивної, дозвіллєвої, тощо. Культура спілкування соціального працівника $€$ потужним резервом підвищення його профресійної культури.

Від рівня соціально-комунікативної культури соціального працівника залежить конкретне вирішення того виду діяльності, елементом якого $є$ спілкування. Професійне спілкування може бути і самостійним видом професійної діяльності соціального працівника, наприклад, налагодження контакту та розуміння між фрахівцем і клієнтом, у якого $є$ проблеми у комунікативній сфері з людьми, фрормування позитивного ставлення клієнта до інших людей, тощо. Основним показником ефективності такої комунікації $€$ задоволеність клієнта стосунками між ним і соціальним працівником, а також результатом вирішення його проблеми.

У науковій роботі Д. Годлевської виокремлено соціально-комунікативний компонент професійної компетентності майбутніх соціальних працівників як базовий, що включає комплекс комунікативних умінь та навичок: визначати цілі та завдання професійного спілкування; володіти голосовими модуляціями; концентрувати увагу; володіти технікою мовлення та соціальної перцепції; логічно будувати діалог, публічні виступи з врахуванням особливостей складу слухачів та їх потреб; викликати позитивну емоційну реакцію від клієнта; аналізува- ти, керувати конфліктними та кризовими ситуаціями, тощо. Науковець переконана, що успішність професійної діяльності соціального працівника у більшості випадків залежить від змісту і рівня його комунікативних умінь, оскільки вони слугують підґрунтям успішної реалізації технологій соціальної роботи у їх практичній діяльності [2, с. 47]

Дослідниця О. Канюк, відповідно до функцій спілкування, систематизує наступні комунікативні уміння майбутнього фрахівця: інформативно-комунікативні (чітко формулювати питання, висловлювати свої думки та позиції, аналізувати, аргументувати, узагальнювати інформацію); інтерактивні (встановлювати контакти зі співрозмовниками, професійно починати діалог, підтримувати, активізувати та закінчувати промову або діалог, залежно від ситуації оптимально обирати стратегію взаємодії, оцінювати комунікативну ситуацію та передбачати подальший іï розвиток); перцептивні (оцінювати емоційний стан, настрій свій та співрозмовника, управляти комунікативною поведінкою, формувати сприятливий соціально-психологічний клімат спілкування тощо) [5, с. 49].

На переконання вченої Н. Волкової комунікативні уміння фрахівця концентрують те, що набуває особистість у процесі педагогічної, практичної і комунікативної діяльності. Дослідниця узагальнює і виокремлює такі групи комунікативних умінь: комунікативно-мовленнєві, невербальні, організаційно-технологічні, інформаційнопошукові, інформаційно-інструментальні. На її думку, комунікативні уміння майбутнього фахівця $€$ внутрішньою моделлю його майбутньої професійної комунікації, яка забезпечує ефективність професійної діяльності в цілому [1, с. 119]. Здатність майбутнього соціального педагога до розвитку комунікативних умінь зростає відповідно до засвоєння ним культурних, ідейноморальних норм та закономірностей суспільства.

Складові соціально-комунікативної культури становлять комунікативний потенціал майбутніх соціальних працівників, який визначає успішність їх спілкування у майбутній професійній діяльності. При цьому все більшої значущості набуває завдання щодо удосконалення процесу формування соціально-комунікативної культури майбутніх соціальних працівників, що $є$ передумовою їх продуктивної профресійної діяльності.

Одним із механізмів формування особистісних якостей у студентському віці є засвоєння соціальних ролей. Поняття соціальної ролі детально розглядається соціальною психологією і часто пов'язується із поняттям соціальної позиції або соціального статусу як об'єктивного місця у соціальній структурі. Досліджуючи комунікативну компетентність особистості у співвідношенні із особливостями виконуваних нею соціальних ролей, Ю. Ємельянов зазначає, що людина зосереджує увагу не на всій загальній культурі суспільства, а тільки на корисній їй у профессійній і повсякденній діяльності [4, с. 85].

На основі проведеного аналізу та узагальнення наукової літератури зміст і структуру "соціальнокомунікативної культури майбутніх соціальних працівників" ми визначаємо як сукупність умінь: встановлювати контакт, будувати та вести діалог, керуючись принципами професійної етики, взаємоповаги і взаєморозуміння 3 клієнтами; використовувати оптимальні моделі поведінки у спілкуванні, толерантного ставлення; переконувати, змінювати хибний світогляд клієнта, який шкодить йому та іншим людям; вести освітню діяльність; налагоджувати стосунки в колективах, доводити свою професійну точку зору та взаємодіяти з партнерами у соціальній роботі тощо.

Таким чином, особливості соціально-комунікативної культури особистості майбутніх соціальних працівників визначаються специфікою культурної і професійної спрямованості освітнього середовища, особистісними якостями та рівнем їх професійної підготовки. Сутність змісту соціально-комунікативної культури майбутнього 
соціального працівника проявляється в особливостях його професійної діяльності, спрямованості на етику та гуманізацію професійних відносин, реалізацію сформованих моральних переконань, ідеалів та культурних цінностей. Відтак, профресійна підготовка соціальних працівників до соціальної роботи є найвідповідальнішою складовою, оскільки майбутніх фрахівців необхідно навчити встановлювати мовний контакт 3 клієнтами, профресійно сприймати, розуміти та використовувати інформацію, з'ясовувати істинні проблеми клієнтів, здійснювати на них ефективний вплив.

Список використаних джерел

1. Волкова Н. П. Професійно-педагогічна комунікація: теорія, технологія, практика / Н. П. Волкова ; Дніпропетр. нац. ун-т. - Дніпропетровськ : Вид-во ДНУ, 2005. - 304 с

2. Годлевська Д. М. Наукові підходи до розуміння змісту поняття "комунікативна компетентність соціального працівника" // Соціальна робота в Україні: теорія і практика. Науково-методичний журнал. - К.: Держсоцслужба, 2005. - №4 (12) жовтень-грудень. - С. 43-50.

3. Грехнев В. С. Культура педагогического общения. - М.: Просвещение, 1990. - 144 с.

4. Емельянов Ю. Н. Активное социально-психологическое обучение. - Ленинград: Издво ЛГУ, 1985. - 168 с

5. Канюк О. Професійні вимоги до майбутніх соціальних працівників / О. Канюк // Актуальні питання гуманітарних наук. - 2015. - Вип. 11. C. 253-259.

6. Капська А. Й., Волинська Л.В., Карпенко О.Г., Филипчук В. С. Комунікативна професійна компетентність як умова взаємодії соціального працівника з клієнтом / За ред. А. Й. Капської. - К.: ДЦСМ, 2003. - 87 с.

7. Мусатов С. О. Гуманістичний потенціал педагогічної комунікації. Книга для вчителя : наук.-метод. посіб. / за ред. С. О. Мусатова. - К. Пед. думка, 2008. - 96 с.

8. Петровська Л. Є. Проблеми міжкультурної і міжмовної відповідності невербальних засобів спілкування (на прикладі жестів ствердження і заперечення у південних слов'ян) / Л. Є. Петровська // Мова і культура. 2011. - Вип. 14, т. 5. - С. 134-138.

9. Савенкова Л. О. Професійне спілкування майбутніх викладачів як об'єкт психолого-педагогічного управління / Л.О.Савенкова - К KHEY, 2005. -212 c

10. Тернопільська В. І. Соціально-комунікативна культура як детермінанта підвищення компетентності майбутніх фахівців В. І. Тернопільська // Наукові записки Вінницького державного педагогі- чного університету імені Михайла Коцюбинського. Серія : Педагогіка і психологія. - 2012. - Вип. 36. - С. 131-135.

11. Спіріна Т. П. Формування професійної культури майбутніх соціальних педагогів у навчально-виховному процесі вищого навчального закладу : автореф. дис. ... канд. пед. наук : спец. 13.00.04 / Спіріна Тетяна Петрівна. - Житомир, 2009. - 19 с.

\section{Reference}

1. Volkova N.P. Profesijno-pedaghoghichna komunikacija: teorija, tekhnologhija, praktyka / N.P. Volkova ; Dnipropetr. nac. un-t. Dnipropetrovsjk : Vyd-vo DNU, 2005. - 304 s.

2. Ghodlevsjka D. M. Naukovi pidkhody do rozuminnja zmistu ponjattja "komunikatyvna kompetentnistj socialjnogho pracivnyka" // Socialjna robota Ukrajini: teorija i praktyka Naukovo-metodychnyj zhurnal - K. Derzhsocsluzhba, 2005. - №4 (12) zhovtenj-ghrudenj. - S. 43-50.

3. Grehnev V.S. Kul'tura pedagogicheskogo obshhenija. M.: Prosveshhenie, 1990. 144 s.

4. Emel'janov Ju. N. Aktivnoe social'no-psihologicheskoe obuchenie. Leningrad: Izdvo LGU, 1985. - $168 \mathrm{~s}$

5. Kanjuk O. Profesijni vymoghy do majbutnikh socialjnykh pracivnykiv / O. Kanjuk // Aktualjni pytannja ghumanitarnykh nauk. - 2015. - Vyp. 11. S. 253-259.

6. Kapsjka A. J., Volynsjka L. V., Karpenko O. Gh., Fylypchuk V.S. Komunikatyvna profesijna kompetentnistj jak umova vzajemodiji socialjnogho pracivnyka z klijentom / Za red. A. J. Kapsjkoji. - K.: DCSM, 2003. $-87 \mathrm{~s}$

7. Musatov S. O. Ghumanistychnyj potencial pedaghoghichnoji komunikaciji. Knygha dlja vchytelja : nauk-metod. posib. / za red. S. O. Musatova. - K. : Ped. dumka, 2008. $-96 \mathrm{~s}$

8. Petrovsjka L. Je. Problemy mizhkuljturnoji i mizhmovnoji vidpovidnosti neverbaljnykh zasobiv spilkuvannja (na prykladi zhestiv stverdzhennja i zaperechennja u pivdennykh slov'jan) / L. Je. Petrovsjka // Mova i kuljtura. 2011. - Vyp. 14, t. 5. - S. 134-138.

9. Savenkova L. O. Profesijne spilkuvannja majbutnikh vykladachiv jak ob'jekt psykhologho-pedaghoghichnogho upravlinnja / L. O. Savenkova. K. : KNEU, 2005. - $212 \mathrm{~s}$

10. Ternopiljsjka V. I. Socialjno-komunikatyvna kuljtura jak determinanta pidvyshhennja kompetentnosti majbutnikh fakhivciv / V. I. Ternopiljsjka /I Naukovi zapysky Vinnycjkogho derzhavnogho pedaghoghichnogho universytetu imeni Mykhajla Kocjubynsjkogho. Serija : Pedaghoghika psykhologhija. - 2012. - Vyp. 36. - S. 131-135

11. Spirina T. P. Formuvannja profesijnoji kuljtury majbutnikh socialjnykh pedaghoghiv u navchaljno-vykhovnomu procesi vyshhogho navchaljnogho zakladu : avtoref. dys. ... kand. ped. nauk : spec. 13.00.04 / Spirina Tetjana Petrivna. - Zhytomyr, 2009. - 19 s.

$$
\text { Надійшла до редколегії 12.11.18 }
$$

Рецензовано 20.11.18

Ya. Spivak, PhD of Pedagogy, Associate Professor

Higher education institution "Donbass State Pedagogical University", Slovyansk, Ukraine

ORCID iD 0000-0001-8829-2236

\section{FUNDAMENTAL IMPORTANCE OF SHAPING SOCIAL AND COMMUNICATIVE CULTURE OF FUTURESOCIAL WORKERS}

The article considers social and communicative culture as a fundamental component of the professionalism of future social workers. The main function of social and communicative culture, which is to establish emotional interaction and communication with clients, is distinguished. Attention is drawn to the fact that the formation of social and communicative culture is an important task of future social workers' training.

The theoretical and methodological basis of social and communicative culture of the personality, in particular, of future social workers, is investigated.

The approaches of scientists to understanding the essence of the concept of 'culture', 'culture of communication', 'social-communicative culture', 'social-communicative culture of a social worker' are analyzed. The relationship between the features of social work and the quality of mastering the communication skills are the basis for the professional competence of the social worker has been clarified. The essence of the content of the socialcommunicative culture of the future social worker is revealed through the focus on ethics and humanization of professional relations, realization of the formed moral convictions, ideals and cultural values, and the structure of the social-communicative culture of future social workers is characterized. The fundamental importance of social and communicative culture has been identified as future professionals need to be trained to establish linguistic contact with clients, perceive professionally, understand and use information, clarify real problems of clients, and influence them effectively.

Keywords: culture of communication, communicative skills, social-communicative culture, social-communicative culture of social worker.

Я. Спивак, канд. пед. наук, доц.

Государственное высшее учебное заведение

"Донбасский государственный педагогический университет", Славянск, Украина

ORCID iD 0000-0001-8829-2236

\section{ФУНДАМЕНТАЛЬНОЕ ЗНАЧЕНИЕ ФОРМИРОВАНИЯ СОЦИАЛЬНО-КОММУНИКАТИВНОЙ КУЛЬТУРЬ БУДУЩИХ СОЦИАЛЬНЫХ РАБОТНИКОВ}

В статье представлена социально-коммуникативная культура как фундаментальная составляющая профессионализма будущих соци альных работников. Выделена основная функция социально-коммуникативной культуры заключающаяся в установлении эмоционального взаимодействия и общения с кпиентами. Акцентировано внимание на том, что формирование социально-коммуникативной культуры является важной задачей подготовки будущих социальных работников.

Исследована теоретико-методологическая основа социально-коммуникативной культуры личности, в частности, будущих социальных работников.

Проанализированы подходы ученых к пониманию сущности понятия «культура», «культура общения», "социально-коммуникативная культура", "социально-коммуникативная культура социального работника". Установлена взаимосвязь между особенностями социальной работы и качеством овладения коммуникативными умениями, которые лежат в основе профессиональной компетенции социального работника. Раскрыта сущность содержания социально-коммуникативной культуры будущего социального работника через направленность на этику и гуманизацию профессиональных отношений, реализацию сформированных нравственных убеждений, идеалов и культурных ценностей. Определены фундаментальные значения социально-коммуникативной культуры поскольку будущих специалистов необходимо научить устанавливать речевой контакт с клиентами, профессионально воспринимать, понимать и использовать информацию, выяснять истинные проблемы клиентов, осуществлять на них эффективное воздействие.

Ключевые слова: культура общения, коммуникативные умения, социально-коммуникативная культура, социально-коммуникативная культура социального работника. 